\title{
Expression of immunoglobulin A in human mesangial cells and its effects on cell apoptosis and adhesion
}

\author{
HUI DENG ${ }^{1 *}$, JUNFAN MA ${ }^{2 *}$, ZIYANG JING ${ }^{1}$, ZHENLING DENG $^{1}$, YAOXIAN LIANG ${ }^{1}$, \\ LATA A $^{1}$, YANG LIU ${ }^{2}$, XIAOYAN QIU ${ }^{2}$ and YUE WANG ${ }^{1}$ \\ ${ }^{1}$ Department of Nephrology, Peking University Third Hospital; ${ }^{2}$ Department of Immunology, \\ Key Laboratory of Medical Immunology, Ministry of Health, School of Basic Medical Sciences, \\ Peking University, Beijing 100191, P.R. China
}

Received July 22, 2017; Accepted January 30, 2018

DOI: $10.3892 / \mathrm{mmr} .2018 .8544$

\begin{abstract}
IgA nephropathy ( $\operatorname{Ig} \mathrm{AN})$ is characterized by predominant $\mathrm{IgA}$ deposition in the glomerular mesangium. It has been considered that the deposited $\operatorname{Ig} \mathrm{A}$ is synthesized by B cells, although recent reports have suggested the implication of other cell types. Therefore, the present study investigated whether glomerular mesangial cells could produce IgA by themselves. Semi-quantitative reverse transcription-polymerase chain reaction, and immunostaining analysis revealed that the $\operatorname{IgA}$ protein and gene transcripts were expressed in primary human renal mesangial cells (HRMCs). Furthermore, the IgA heavy chain $(\alpha 1$ and $\alpha 2)$ and the light chain ( $\kappa$ and $\lambda$ ) were localized in the cytoplasm or were located on the cell membranes of human mesangial cells (HMCs). Mass spectrometry results indicated that Ig $\alpha 1$ and Ig $\alpha 2$ were secreted in the culture media of HMCs. The transcripts of $\operatorname{Ig} \alpha, \operatorname{Ig} \kappa$ and $\operatorname{Ig} \lambda$ constant regions were detected. The predominant rearrangement pattern of the variable region of $\operatorname{Ig} \kappa$, was $\mathrm{V}_{\kappa} 3-20 * 01 / \mathrm{J}_{\kappa} 1 * 01$ in HMCs and $\mathrm{V}_{\kappa} 1-12 * 01 / \mathrm{J}_{\kappa} 4 * 01$ in HRMCs. In addition, knockdown of Ig $\alpha 1$ expression by small interfering RNA (siRNA) inhibited cell adhesion and promoted apoptosis. Our findings
\end{abstract}

Correspondence to: Professor Yue Wang, Department of Nephrology, Peking University Third Hospital, 49 Garden Northern Road, Beijing 100191, P.R. China

E-mail: bjwangyue@sina.com

Professor Xiaoyan Qiu, Department of Immunology, Key Laboratory of Medical Immunology, Ministry of Health, School of Basic Medical Sciences, Peking University, 38 Xueyuan Road, Beijing 100191, P.R. China

E-mail: qiuxy2014@126.com

*Contributed equally

Abbreviations: HMC, human mesangial cell; AngII, angiotensin II; SAC, staphylococcus; siRNA, small interfering RNA

Key words: mesangial cell, IgA nephropathy, apoptosis, gene expression, renal pathology demonstrate that HMCs can express IgA, and that this expression is associated with cell functions, which may contribute to the deposition of IgA in patients with IgAN.

\section{Introduction}

Human mesangial cell (HMC) proliferation and expansion occurs in major glomerular diseases and is the main feature of IgA nephropathy (IgAN) (1). It is generally considered that the immune complexes containing IgA are found in the glomerular mesangium, and that IgA1 is secreted by B lymphocytes, mediated by the process of glycosylation and over aggregation. The abnormal IgA1 can be recognized by anti-glycan auto-antibodies of the IgA1 and/or IgG isotype, resulting in formation of circulative immune complexes (CIC) $(2,3)$. The pathogenic CIC deposits in the glomerular mesangium can promote resident mesangial cells to secrete proinflammatory factors, initiating glomerular injuries (4-6).

Classical immunology considers that differentiated B cells are the unique source of immunoglobulins (Igs). However, this theory has been challenged over the past decade by increasing evidence reporting that Igs could be expressed in cancer cells. Qiu and Yang initially reported the existence of Ig-like protein in malignant tumor cells in $1996(7,8)$. Later studies by Kimoto and Zheng et al have shown that Igs transcripts are expressed in human carcinoma cell lines (9), and in human epithelial carcinoma cell lines (10). Qiu et al also has reported IgG secretion by epithelial cancer cells, and demonstrated that its function is to promote growth and survival of tumor cells (11). Subsequently, Igs were found to be widely expressed in many types of cancer cells, including breast cancer, colon cancer, lung carcinomas, nasopharyngeal carcinoma, abnormal cervical epithelial cells and oral epithelial tumor cells (12-16). Unlike B-cell-derived Igs, which are the key molecules for humoral immune responses, cancerous Igs are associated with various cell functions, such as cell survival, proliferation, transformation, metastasis and carcinogenesis (11,13,17-22).

Besides the cancer cells, there is growing evidence showing that normal cells could also express Igs. Huang et al reported that several types of Igs are expressed in normal cells, including IgG expression in brain neurons with classic $\mathrm{V}$-(D)-J gene rearrangements (23), Ig $\mu$ gene expression and 
rearrangement in myeloid cells (24), Ig gene expression and rearrangement in germ cells (25), mammary gland (26) and hematopoietic stem/progenitor cells (27). Kang et al revealed the LOX-1 dependent overexpression of Ig $\kappa$ in cardiomyocytes in response to angiotensin II (AngII) (28). Previous results detected the $\operatorname{IgG}$ expression in the eye (29), and the $\operatorname{IgG}, \operatorname{IgA}$, IgM expression in the liver (30) and in the hippocampus (31). These findings demonstrated that normal cells could express proteins and mRNA transcripts of the Ig's heavy chains, light chains, and enzymes required for $\mathrm{V}(\mathrm{D}) \mathrm{J}$ recombination, suggesting a significant role in maintaining the organs' microenvironment, and regulating the development and function of cells.

In the present study, we have confirmed that $\operatorname{IgA}$ is expressed in primary human renal mesangial cells (HRMCs) and in the HMCs, and investigated its potential role on cell apoptosis and cell adhesion.

\section{Materials and methods}

Cell culture. Primary HRMCs (Sciencell Research Laboratories, Carlsbad, CA, USA) were cultured in mesangial cell medium (MCM) solution containing 2\% FBS, $1 \%$ mesangial cell growth supplement, and $1 \%$ penicillin/streptomycin. The materials to culture HRMCs were purchased from the Sciencell Research Laboratories and cultured according to the manufacturer's protocol. Cells were maintained in serum-free medium for $48 \mathrm{~h}$ prior to harvesting. Cells were used at passage nos. 4 to 6 .

The HMC line, C2M12, which retains many of the morphological and physiological features of the normal HMCs $(32,33)$, was kindly donated by Professor Youfei Guan (Department of Physiology and Pathophysiology, Peking University Health Science Center, Peking, China). These cells were cultured in RPMI-1640 (Gibco; Thermo Fisher Scientific, Inc., Waltham, MA, USA) containing $10 \%$ fetal bovine serum (FBS; Biological Industries USA, Inc., Cromwell, CT, USA), $1 \%$ insulin transferrin selenium-A supplement (ITS-A; Invitrogen; Thermo Fisher Scientific, Inc.), $100 \mathrm{U} / \mathrm{ml}$ penicillin, and $100 \mathrm{mg} / \mathrm{ml}$ streptomycin, at $37^{\circ} \mathrm{C}$ in an atmosphere of $95 \%$ air and $5 \% \mathrm{CO}_{2}$. Cells were sub-cultured when reaching $90 \%$ confluency with $0.05 \%$ trypsin containing $1 \mathrm{mM}$ EDTA for $20 \mathrm{sec}$ at $37^{\circ} \mathrm{C}$. AngII and staphylococcus (SAC; Sigma-Aldrich, St. Louis, MO, USA) were used to stimulate the HMCs.

Cell cycle synchronization. Cell cycle synchronization of the HMCs was performed following the double thymidine block protocol described by previous studies $(34,35)$. Briefly, HMCs were seeded on $10 \mathrm{~cm}$ culture dishes at a density of $1 \times 10^{5}$ cells per dish. In order to collect cells arrested at G1/S phase, the cell culture was grown until it reached confluence of $50 \%$, then arrested with $2 \mathrm{mmol} / \mathrm{l}$ thymidine in complete culture media for $12 \mathrm{~h}$, washed twice with phosphate-buffered saline (PBS), and recovered in fresh complete culture media for $12 \mathrm{~h}$, followed by a second arrest with $2 \mathrm{mmol} / \mathrm{l}$ thymidine for another $12 \mathrm{~h}$. After the second arrest, the supernatant was replaced by fresh complete culture media to recover the cells. A sample of each cell culture was collected on cover slips every $2 \mathrm{~h}$ after the second cell cycle release.
Cell cycle assay. Cell cycle progression was assessed by flow cytometry based on the DNA content of cells (36). DNA content of cells at distinct phases of the cell cycle (G0/G1, S, and $\mathrm{G} 2 / \mathrm{M}$ phase) was analyzed using propidium iodide (PI) staining. HMCs were harvested and washed twice in cold PBS by centrifugation at $800 \times \mathrm{g}$ for $5 \mathrm{~min}$. Cells were then suspended in $100 \mu \mathrm{l}$ ice-cold PBS at a density of at least $2 \times 10^{4}$ cells per tube. $3 \mathrm{ml}$ of ice-cold $70 \%$ ethanol was gradually added to the cell suspension for fixation. The suspended cells were incubated at $4^{\circ} \mathrm{C}$ overnight, then filtered through a $48 \mu \mathrm{m}$ filter screen, spun at 1,500 $\mathrm{x}$ g for $5 \mathrm{~min}$ and washed twice with ice-cold PBS to remove traces of ethanol. RNase $(0.5 \mathrm{mg} / \mathrm{ml})$ was added to degrade RNA at $37^{\circ} \mathrm{C}$ for $30 \mathrm{~min}$. After washing twice with $300 \mu \mathrm{l}$ ice-cold PBS, the cells were suspended in 300 of $50 \mu \mathrm{g} / \mathrm{ml}$ PI staining solution to stain the nuclei and incubated at room temperature for $5 \mathrm{~min}$ in the dark. The cell cycle data for individual samples was acquired using the BD LSRFortessa ${ }^{\mathrm{TM}}$ flow cytometer equipped with BD FACSDiva $^{\mathrm{TM}}$ software (BD Biosciences, San Diego, CA, USA) and analyzed using ModFit LT $^{\mathrm{TM}}$ software (Verity Software House, Topsham, ME, USA).

Immunofluorescence. For indirect immunofluorescence staining (IF), HMCs and HRMCs were cultured on cover slips and fixed in cold acetone for $5 \mathrm{~min}$. After washing three times with PBS, the slides were blocked with 5\% BSA (Invitrogen; Thermo Fisher Scientific, Inc.) (diluted with PBS) for $30 \mathrm{~min}$ at room temperature and incubated with the primary antibody (diluted with PBS) at $4^{\circ} \mathrm{C}$ overnight. Mouse anti-human Ig $\alpha 1$, Ig $\alpha 2$ antibodies (Southern-Biotech, Birmingham, AL, USA), mouse anti-human monoclonal $\operatorname{Ig} \kappa$, Ig $\lambda$ antibodies (Zhongshan Golden Bridge Biotechnology Co., Ltd., Beijing, China) were used as the primary antibody; PBS was used as a blank control. After removing the unbound antibodies by washing in PBS for three times, the slides were incubated with goat anti-mouse IgG antibody (Zhongshan Golden Bridge Biotechnology Co., Ltd.) and labeled with fluorescein isothiocyanate (FITC) for $1 \mathrm{~h}$ at room temperature in dark. For direct immunofluorescence staining, the slides were incubated with the mouse anti-human Ig $\alpha$-FITC (Zhongshan Golden Bridge Biotechnology Co., Ltd.) in the dark overnight at $4^{\circ} \mathrm{C}$. After washing another three times, the slides were incubated with DAPI (Vector Laboratories, Inc., Burlingame, CA, USA) for $2 \mathrm{~min}$ at room temperature. Fluorescent signals were detected with a Confocal Laser Scanning microscopy FV1000 (Olympus, Tokyo, Japan).

Semi-quantitative reverse transcription-polymerase chain reaction ( $S q R T-P C R)$. Total RNA of cultured cells was extracted with TRIzol reagent (Invitrogen; Thermo Fisher Scientific, Inc.) and the concentration was assessed using a Nanodrop spectrophotometer (Thermo Fisher Scientific, Inc.). Then $1.5 \mu \mathrm{g}$ of total RNA was reverse-transcribed to cDNA using the GoScript ${ }^{\mathrm{TM}}$ Reverse Transcriptase (Promega, Madison, WI, USA). PCR was performed with the primers targeting constant regions of $\operatorname{Ig} \alpha, \operatorname{Ig} \kappa, \operatorname{Ig} \lambda(\operatorname{Ig} \mathrm{C} \alpha, \operatorname{Ig} \mathrm{C} \kappa$, $\operatorname{Ig} \mathrm{C} \lambda$ ) and nested PCR was performed with external primers at the first round and internal primers at the second round targeting variable region of $\mathrm{Ig} \kappa(\mathrm{Ig} \mathrm{V} \kappa)$. The sequences of primers and reaction conditions are listed in Tables I and II. 
Table I. Sequences of polymerase chain reaction primers used in this study.

\begin{tabular}{|c|c|c|c|}
\hline Gene name & Primer & Primer sequence $5{ }^{\prime}-3^{\prime}$ & Product length (bp) \\
\hline \multirow[t]{2}{*}{ Ig $\alpha$ constant region $(\operatorname{Ig} C \alpha)$} & Forward & ACCATGCAGGAGAAGGTGTC & 340 \\
\hline & Reverse & TCACTTGCACTGCTGCCTAC & \\
\hline \multirow[t]{2}{*}{ Igא constant region ( $\operatorname{Ig} \mathrm{C} \kappa)$} & Forward & TGAGCAAAGCAGACTACGAGA & 231 \\
\hline & Reverse & GGGGTGAGGTGAAAGATGAG & \\
\hline \multirow[t]{2}{*}{$\operatorname{Ig} \lambda$ constant region $(\operatorname{Ig} C \lambda)$} & Forward & GGGACCAAGCTCACCGTCCTAG & 316 \\
\hline & Reverse & TCTTCTCCACGGTGCTCCCTTC & \\
\hline \multirow[t]{4}{*}{ Igк variable region $(\mathrm{Ig} \mathrm{V \kappa})$} & External forward & GACATCGAGCTCACCCAGTCTCC & $360-380$ \\
\hline & External reverse & CGGGAAGATGAAGACAGATGGTGC & \\
\hline & Internal forward & GAAATTGAGCTCACGCAGTCTCCA & $340-360$ \\
\hline & Internal reverse & TGGTGCAGCCACAGTTCGTT & \\
\hline \multirow[t]{2}{*}{$\beta$-actin } & Forward & AGAGCTATGAGCTGCCTGAC & 121 \\
\hline & Reverse & AATTGAATGTAGTTTCATGGATG & \\
\hline
\end{tabular}

Table II. Reaction conditions of polymerase chain reaction used in this study.

\begin{tabular}{|c|c|c|c|c|c|c|}
\hline $\begin{array}{l}\text { Gene } \\
\text { name }\end{array}$ & $\begin{array}{c}\text { Initial } \\
\text { denaturation }\left({ }^{\circ} \mathrm{C} / \mathrm{min}\right)\end{array}$ & $\begin{array}{l}\text { Denaturation } \\
\left({ }^{\circ} \mathrm{C} / \mathrm{sec}\right)\end{array}$ & $\begin{array}{l}\text { Annealing } \\
\left({ }^{\circ} \mathrm{C} / \mathrm{sec}\right)\end{array}$ & $\begin{array}{l}\text { Extension } \\
\left({ }^{\circ} \mathrm{C} / \mathrm{sec}\right)\end{array}$ & $\begin{array}{l}\text { Cycle } \\
\text { number }\end{array}$ & $\begin{array}{c}\text { Extension } \\
\left({ }^{\circ} \mathrm{C} / \mathrm{min}\right)\end{array}$ \\
\hline $\operatorname{Ig~C} \alpha$ & $94 / 4$ & $94 / 30$ & $62 / 30$ & $72 / 30$ & 35 & $72 / 10$ \\
\hline $\operatorname{Ig~C\kappa }$ & $95 / 4$ & $95 / 30$ & $50 / 30$ & $72 / 30$ & 35 & $72 / 10$ \\
\hline $\operatorname{Ig} \mathrm{C} \lambda$ & $95 / 4$ & $95 / 30$ & $56 / 30$ & $72 / 30$ & 35 & $72 / 10$ \\
\hline \multirow[t]{7}{*}{ Ig Vк (External reaction) } & $94 / 5$ & $94 / 30$ & $60 / 30$ & $72 / 30$ & 3 & - \\
\hline & & $94 / 30$ & $58 / 30$ & $72 / 30$ & 3 & - \\
\hline & & $94 / 30$ & $56 / 30$ & $72 / 30$ & 3 & - \\
\hline & & $94 / 30$ & $54 / 30$ & $72 / 30$ & 3 & - \\
\hline & & $94 / 30$ & $52 / 30$ & $72 / 30$ & 3 & - \\
\hline & & $94 / 30$ & $50 / 30$ & $72 / 30$ & 3 & - \\
\hline & & $94 / 30$ & $48 / 30$ & $72 / 30$ & 20 & $72 / 7$ \\
\hline Ig Vк (Internal reaction) & $94 / 5$ & $94 / 30$ & $60 / 30$ & $72 / 30$ & 35 & $72 / 7$ \\
\hline$\beta$-actin & $94 / 5$ & $94 / 30$ & $56 / 30$ & $72 / 30$ & 25 & $72 / 7$ \\
\hline
\end{tabular}

Amplification products were separated in a $1 \%$ agarose gel by electrophoresis, including a 100 bp DNA ladder (Beijing Solarbio Science \& Technology Co., Ltd., Beijing, China). The amplified DNA fragments were identified by their molecular mass, under ultraviolet light observations. Human peripheral blood mononuclear cells (PBMCs) were used as the positive control. The peripheral blood was obtained from healthy donors. PBMCs were isolated from $5 \mathrm{ml}$ peripheral blood using two-step discontinuous Ficoll/Hypaque (Second Chemistry Factory, Shanghai, China) density gradient centrifugation. The white gradient layer containing PBMCs was recovered and washed with 0.01 M PBS, and the isolated PBMCs used immediately for total RNA extraction (37).

Analysis of gene rearrangement. PCR products of Ig Vк were cloned into a pGEM-T Easy Vector (Promega) and transfected into the competent $E$. coli cell line TOP10 [Tiangen Biotech (Beijing) Co., Ltd., Beijing, China]. The transcripts of individual clones were amplified. After DNA sequencing with an ABI 3730XL Genetic Analyzer (Applied Biosystems;
Thermo Fisher Scientific, Inc.) which was performed by Invitrogen; Thermo Fisher Scientific, Inc., the variable sequences were compared with the published sequences of the germline gene segments using the BLAST tool of the National Center for Biotechnology Information (NCBI).

Western blot analysis. Cultured cells were harvested and washed twice with cold PBS, then re-suspended in TSD lysis buffer (TSD lysis buffer, 1\% SDS; $50 \mathrm{mmol} / 1$, pH 7.5 Tris-HCL, $50 \mathrm{mmol} / 1 \mathrm{DTT}$ ), sonicated for $1 \mathrm{~min}$, and lysed for $30 \mathrm{~min}$ at room temperature. The protein concentration of the cell lysate was calculated with a BCA kit (Applygen Technologies Inc., Beijing, China). After centrifugation at $12,000 \mathrm{x} \mathrm{g}$ for $10 \mathrm{~min}$ at $4^{\circ} \mathrm{C}, 5 \mathrm{X}$ loading buffer was added to the lysate, boiled at $100^{\circ} \mathrm{C}$ for $5 \mathrm{~min}$, and the samples were immediately used for western blot analysis. The proteins in the culture supernatant were precipitated with $50 \%$ ammonium sulfate, centrifuged at $12,000 \mathrm{x} \mathrm{g}$ for $15 \mathrm{~min}$ and then dissolved in PBS. The collected fraction was filtrated with the AmiconR Ultra-0.5 Centrifugal Filter Devices (EMD 
Millipore, Billerica, MA, USA) to remove the ammonium sulfate. The measurement of protein concentration in the culture supernatant was performed with the same method used as for the cell lysate. Free Ig in the human serum and the cultural medium were used as control.

The protein samples were separated by $10 \%$ sodium dodecylsulfate-polyacrylamide gel electrophoresis (SDS-PAGE) and transferred to nitrocellulose membranes. The membranes were incubated with rabbit anti-IgA antibody $(1: 1,000)$, mouse anti-IgA1 antibody $(1: 1,000)$, mouse anti-IgA2 antibody $(1: 1,000)$, rabbit anti-Ig $\kappa$ antibody $(1: 10,000)$, and rabbit anti-Ig $\lambda$ antibody $(1: 50,000)$. The above antibodies were purchased from Abcam (Cambridge, UK). All the membranes were washed three times with TBST for $10 \mathrm{~min}$ before incubated with secondary antibodies for $1 \mathrm{~h}$ at room temperature. Goat anti-rabbit IgG-IRDyeTM800CW (1:10,000 and goat anti-mouse IgG-IRDyeTM680CW (1:10,000; both from LI-COR Biosciences, Lincoln, NE, USA) were used as secondary antibodies. Immunoreactivity was observed with the Odyssey Infrared imager (LI-COR Biosciences).

IgAl purification and mass spectrometry. After the HMCs were cultured in RPMI-1640 with $2 \%$ FBS for $48 \mathrm{~h}$, the culture supernatant was collected as described above. $\operatorname{Ig} \mathrm{A} 1$ was purified according to the manufacturer's instructions of jacalin-sepharose (BioVision, Milpitas, CA, USA). After precipitation of the proteins, the pellet was dissolved in PBS and filtrated with the AmiconR Ultra-0.5 Centrifugal Filter Devices (EMD Millipore) to remove the ammonium sulfate and elution buffer. The purified proteins were separated by $10 \%$ SDS PAGE, detected by western blot analysis as described above, and further analyzed by mass spectrometry in the Beijing Protein Innovation Co., Ltd. (Beijing, China).

Cell stimulation with AngII. HMC were seeded on $10 \mathrm{~cm}$ culture dishes. When the sub-cultured HMC reached $70 \%$ confluency, cells were cultured in RPIM-1640 containing $0.5 \%$ FBS overnight, followed by treatment with $10^{-8} \mathrm{~mol} / \mathrm{l}$ AngII for $24 \mathrm{~h}$ or with SAC $(1: 1,000)$ for $48 \mathrm{~h}$. A sample from each cell culture was placed on cover slips for immunostaining and the remaining cells were collected for western blot analysis, as described above.

Transfection of cultured HMCs with small interfering RNA (siRNA). Lipofectamine 3000 (Invitrogen; Thermo Fisher Scientific, Inc.) was used for the transfection with siRNA. siRNAs directed against different regions of the constant region of the Ig $\alpha 1$ heavy chain (siRNA-1, siRNA-2 and siRNA-3), against GAPDH (positive control, PC) and against the nonspecific, scrambled, control siRNA [negative control (NC)], were designed by GenePharma Company (Shanghai, China) and the sequences are listed in Table III. HMCs were seeded onto 12 -well culture plate $\left(2 \times 10^{4}\right.$ cells/well $)$ in mesangial cell culture media and grown overnight. HMCs were then transfected with each of $50 \mathrm{nmol} / 1 \mathrm{siRNA}$ mixed with Lipofectamine reagent in Opti-mem medium (Invitrogen; Thermo Fisher Scientific, Inc.). PBS was added to the control group. HMCs were harvested after transfection for $48 \mathrm{~h}$ and used for western blot analysis.
Table III. Sequences of siRNA used in this study.

\begin{tabular}{llc}
\hline siRNA & Direction & \multicolumn{1}{c}{ Sequence (5'-3') } \\
\hline siRNA-1 & $\begin{array}{l}\text { Forward } \\
\text { Reverse }\end{array}$ & $\begin{array}{l}\text { GCUCUUAGGUUCAGAAGCGTT } \\
\text { CGCUCUGAACCUAAGAGCTT }\end{array}$ \\
siRNA-2 & $\begin{array}{l}\text { Forward } \\
\text { GGAACCAUGGGAAGACCUUTT }\end{array}$ & $\begin{array}{l}\text { Reverse } \\
\text { AAGGUCUUCCCAUGGUUCCTT }\end{array}$ \\
siRNA-3 & $\begin{array}{l}\text { Forward } \\
\text { Positive }\end{array}$ & FCCUUCACACAGAAGACCATT \\
control & Forward & UGACCUCAACUACAUGGUUTT \\
& Reverse & AACCAUGUAGUUGAGGUCATT \\
Negative & Forward & UUCUCCGAACGUGUCACGUTT \\
control & & \\
& Reverse & ACGUGACACGUUCGGAGAATT
\end{tabular}

siRNA, small interfering RNA.

Table IV. Rearrangement patterns of Ig $\kappa$ variable region transcripts.

\begin{tabular}{lcccc}
\hline Name & Clone no. & $\mathrm{V} \kappa$ & $\mathrm{J} \kappa$ & Identity\% \\
\hline PBMC (n=16) & 1 & $\mathrm{~V} \kappa 1-27 * 01$ & $\mathrm{~J} \kappa 1 * 01$ & 90.2 \\
& 1 & $\mathrm{~V} \kappa 1-27 * 01$ & $\mathrm{~J} \kappa 4 * 01$ & 96.1 \\
& 1 & $\mathrm{~V} \kappa 1-39 * 01$ & $\mathrm{~J} \kappa 1 * 01$ & 90.8 \\
& 6 & $\mathrm{~V} \kappa 1-39 * 01$ & $\mathrm{~J} \kappa 4 * 01$ & $86.9-97.6$ \\
& 1 & $\mathrm{~V} \kappa 1-39 * 01$ & $\mathrm{~J} \kappa 3 * 01$ & 97.9 \\
& 1 & $\mathrm{~V} \kappa 1-39 * 01$ & $\mathrm{~J} \kappa 5 * 01$ & 93.3 \\
& 1 & $\mathrm{~V} \kappa 1-16 * 02$ & $\mathrm{~J} \kappa 4 * 01$ & 95.5 \\
$\operatorname{HMC}(\mathrm{n}=7)$ & 2 & $\mathrm{~V} \kappa 1-33 * 01$ & $\mathrm{~J} \kappa 4 * 01$ & 91.3 \\
$\operatorname{HRMC}(\mathrm{n}=8)$ & 1 & $\mathrm{Vk} 4-1 * 01$ & $\mathrm{Jk} 4 * 01$ & 96.6 \\
& 2 & $\mathrm{~V} \kappa 3-20 * 01$ & $\mathrm{~J} \kappa 1 * 01$ & 94.4 \\
& 6 & $\mathrm{~V} \kappa 3-20 * 01$ & $\mathrm{~J} \kappa 1 * 01$ & $92.7-94.4$ \\
& & $\mathrm{Vk} 1-12 * 01$ & $\mathrm{Jk} 4 * 01$ & $94.4-94.7$ \\
\hline
\end{tabular}

PBMC, peripheral blood mononuclear cell; HMC, human mesangial cell; HRMC, human renal mesangial cell.

Cell apoptosis assay. After transfection for 48 h, cells were collected with $0.05 \%$ trypsin solution and harvested by centrifugation at $800 \mathrm{x} \mathrm{g}$ for $5 \mathrm{~min}$. The harvested cells were washed twice with cold PBS. According to the manufacturer's protocol, $1 \times 10^{6}$ cells were suspended in $100 \mu \mathrm{l}$ of $1 \mathrm{X}$ Annexin $\mathrm{V}$ binding buffer and stained with $5 \mu \mathrm{l}$ of Annexin V-FITC and $5 \mu \mathrm{l}$ of 7-AAD (both from BD Biosciences) in the dark for 15 min at room temperature. After adding another $400 \mu \mathrm{l}$ binding buffer and filtrating through a $48 \mu \mathrm{m}$ filter, cell apoptosis was measured by flow cytometry (BD Biosciences).

Cell adhesion assay. Cell adhesion rate was analyzed by the Cell Counting kit-8 (CCK-8; Dojindo Molecular Technologies, Inc., Kumamoto, Japan). After siRNA transfection for $48 \mathrm{~h}$, $3 \times 10^{4}$ cells were re-suspended in culture media and $100 \mu 1$ were 
A

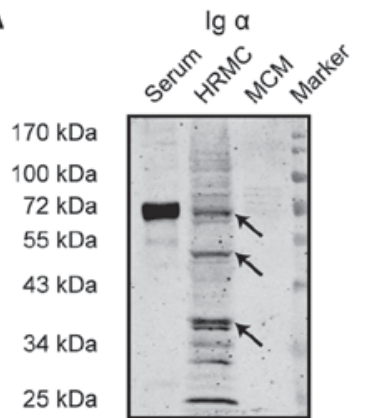

B

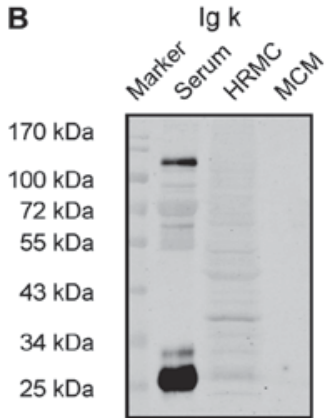

C

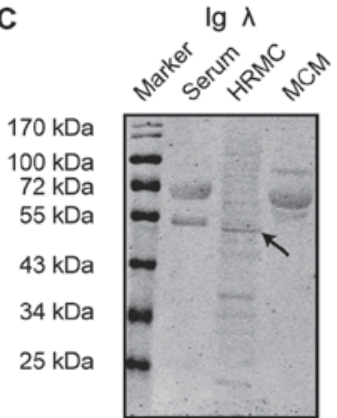

D

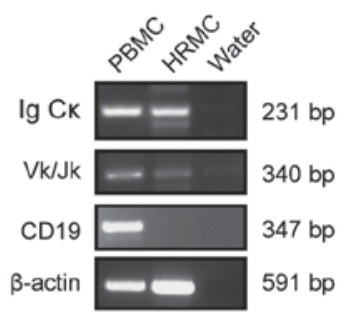

E mRNA 672 CATCAGGGCCTGAGCTCGCCCGTCACAAAGAGCTTCAACAGGGGAGAGTGTTAGAGGGAGAAGTGCCCCCACCTGCTCCTCAGTTCCAGCCT 763

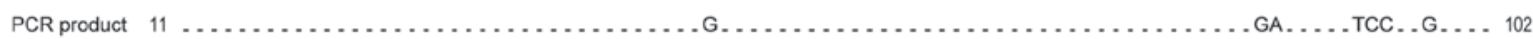

mRNA 764 GACCCCCTCCCATCCTTTGGCCTCTGACCCTTTTTCCACAGGGGACCTACCCCTATTGCGGTCCTCCAGCTCATCTTTCACCTCAC 849

PCR product $103 \quad$. C . . . . . . . . . . . . . . . . . . . . . . . . . . . . . . . . . . . . . . . . 188

Figure 1. IgA expression in HRMCs. (A-C) Ig $\alpha$ and Ig $\lambda$ bands detected in the primary human renal mesangial cell lysate and the human serum as a positive

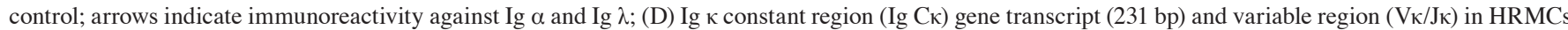

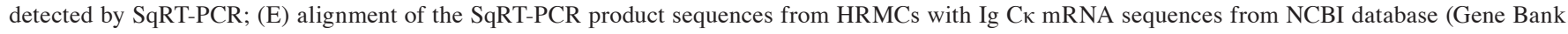
Y14736.1). Negative control: PCR reaction mixture with water; CD19: B lymphocyte marker. HRMC, human renal mesangial cell; SqRT-PCR, semi-quantitative reverse transcription-polymerase chain reaction; NCBI, National Center for Biotechnology Information; MCM, mesangial cell medium; PBMC, peripheral blood mononuclear cell.

aliquoted in each well of a 96-well plate and incubated at $37^{\circ} \mathrm{C}$ for 1 h. 3 wells of each group were washed gently three times with PBS, and $100 \mu 1$ of fresh culture media with $8 \mu 1$ of CCK-8 reagents were added. In order to analyze the total cell concentration, CCK-8 was directly added to 3 different unwashed wells. After incubation for $3 \mathrm{~h}$ at $37^{\circ} \mathrm{C}$, concentration was determined by measuring absorbance at $450 \mathrm{~nm}$ using a spectrophotometric microplate reader (BioTek Instruments, Inc., Winooski, VT, USA). The cell adhesion rate was calculated as follows:

$$
\text { Cell adhesion rate }=\frac{O D_{\text {washed }}-O D_{\text {blank }}}{O D_{\text {unwashed }}-O D_{\text {blank }}}
$$

Statistical analysis. Data was expressed as the means \pm standard deviation and analyzed using SPSS 20.0 for Windows (SPSS, Inc., Chicago, IL, USA). The differences between experimental groups were analyzed with one-way analysis of variance, followed by a Least Square Difference multiple comparison test. A value of $\mathrm{P}<0.05$ was considered to indicate a statistically significant difference.

\section{Results}

IgA expression in primary HMCs. In this study, the in vivo IgA expression in HRMCs was investigated. Western blot analysis of the lysed HRMCs demonstrated that Ig $\alpha$ was present not only at a size of $72 \mathrm{kDa}$, which was consistent with the positive control in the serum, but also at 53 and $38 \mathrm{kDa}$ (Fig. 1A), indicating that the $\alpha$ chains in the cytoplasm might be truncated or are at different synthesis stages. There was no obvious band detected for Ig $\kappa$ (Fig. 1B). A positive band for Ig $\lambda$ was detected at $55 \mathrm{kDa}$ which is similar to the molecular weight of a dimer and was consisted with the size of the positive controls in the serum (Fig. 1C). The absence of a band in the MCM eliminates the possibility of $\operatorname{IgA}$ heavy chain and light chain expression in the culture medium. In addition,

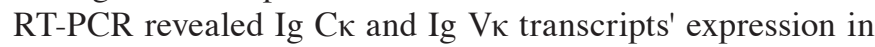

HRMCs (Fig. 1D). Further sequencing of the PCR products

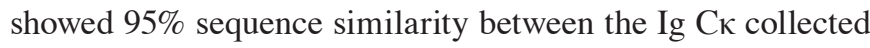
from the HRMCs and the published sequence obtained from plasma cells in the NCBI database (Gene Bank, Y14736.1) (Fig. 1E). The predominant $\mathrm{V} \kappa / \mathrm{J} \kappa$ rearrangement pattern was V $1-12 * 01 / \mathrm{J} \kappa 4 * 01$, which is different to the transcripts' pattern observed in the PBMCs (Table IV). The negative expression of CD19 indicated that there was no B cell contamination in the HRMCs. The constant region and the Ig Vא transcripts were strongly detected, suggesting an IgA expression in the HRMCs.

IgA expression in HMC line. IgA expression in mesangial cells was further confirmed in the HMC cell line with several methods. Immunofluorescence staining was positive for $\operatorname{Ig} \alpha, \operatorname{Ig} \kappa, \operatorname{Ig} \lambda$ in the mesangial cytoplasm (Fig. 2A). Similar to a previous study which had reported the absence of IgA in the FBS (38), the FBS was negatively stained with rabbit anti-human Ig $\alpha, \kappa$ and $\lambda$ antibodies, indicating that FBS could not interfere with the results. Western blot analysis of the HMCs lysates displayed similar positive bands for Ig $\alpha$ at 53 and $38 \mathrm{kDa}$, and for Ig $\lambda$ at $55 \mathrm{kDa}$, but negative results for Ig $\kappa$, which corresponds with the results obtained in HRMCs (Fig. 2B), further supporting the IgA expression in mesangial cells.

Ig gene rearrangement and transcription is a prerequisite for Ig expression. To confirm the fact that IgA was synthesized in HMCs, we further explored the transcripts of $\operatorname{Ig} \alpha, \operatorname{Ig} \kappa$ and Ig $\lambda$ by examining the mRNA expression of the constant regions of $\operatorname{Ig} \alpha, \operatorname{Ig} \kappa, \operatorname{Ig} \lambda$ and the variable region of Ig $\kappa$ in the HMCs (Fig. 2C). The alignment of the sequences of the RT-PCR products with those of the published Ig C $\alpha 1$, Ig $\mathrm{C} \alpha 2$, Ig $\mathrm{C} \kappa$ and Ig $\mathrm{C} \lambda$ mRNA sequences in the NCBI database (Gene Bank, BC016369.1, BC073765.1, Y14736.1, X57823.1) demonstrated a sequence similarity of $99,97,98$ and $97 \%$, respectively

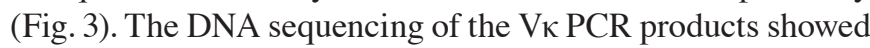
that the predominant rearrangement was $\mathrm{V} \kappa 3-20 * 01 / \mathrm{J} \kappa 1 * 01$, which was different from the rearrangements in HRMCs, 
A a

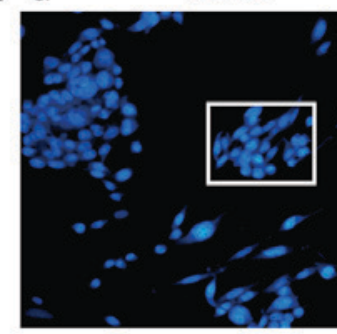

e

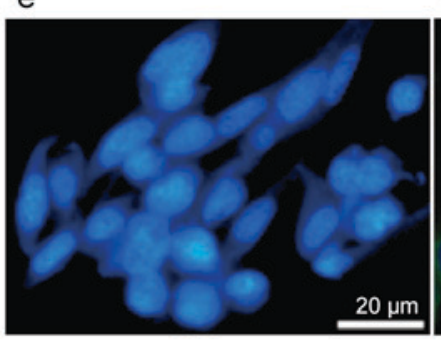

b

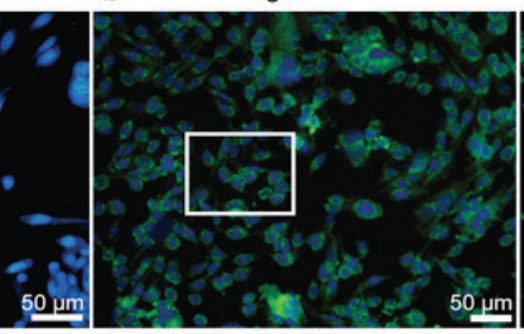

$f$

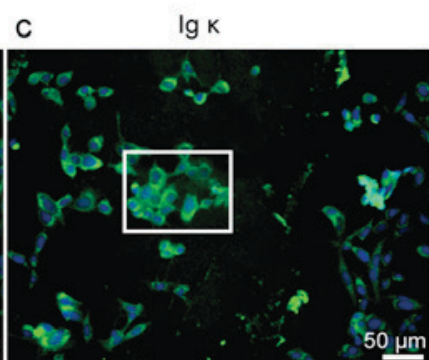

g d $\quad \lg \lambda$

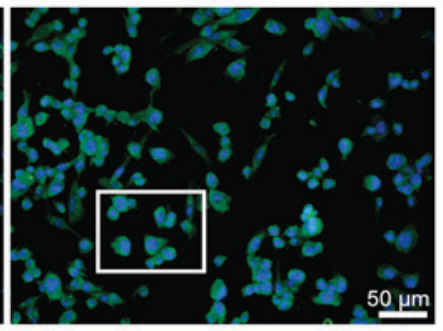

h
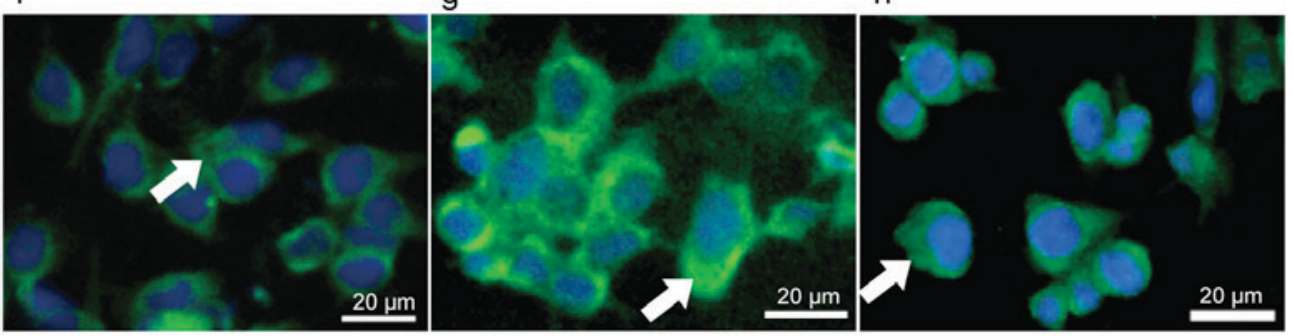

B

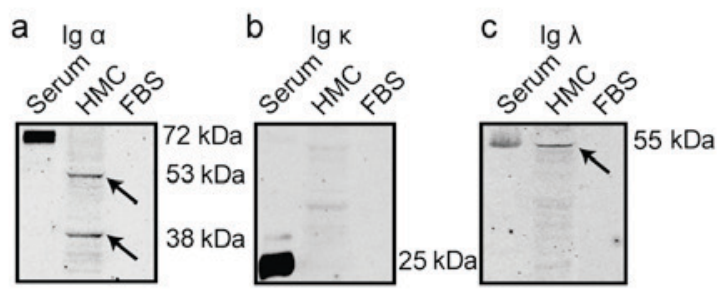

C

Ig Ca
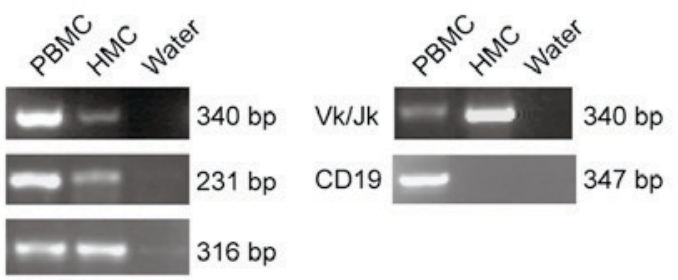

$\lg \mathrm{C} \lambda$

$\lg \mathrm{C}_{\mathrm{K}}$

Figure 2. IgA expression in HMCs. (A) Positive immunofluorescence staining of $\operatorname{Ig} \alpha$ (b and f), Ig $\kappa$ (c and g) and $\operatorname{Ig} \lambda$ (d and h) in HMCs, (a and e) were the blank controls with PBS replacing primary antibodies; Green, antibody staining; blue, nuclear staining by DAPI; scale bar, $50 \mu \mathrm{m}$ (upper), $20 \mu \mathrm{m}$ (lower); (B) $\operatorname{Ig} \alpha$ (a), Ig $\kappa$ (b), Ig $\lambda$ (c) detected in human glomerular mesangial cell line lysates and human serum as a positive control; arrows indicate immunoreactivity against Ig $\alpha$ and $\operatorname{Ig} \lambda$; (C) Ig $\alpha$ heavy chain constant region (Ig C $\alpha$ ), Ig $\kappa$ light chain constant region (Ig $\mathrm{C} \kappa)$, Ig $\lambda$ light chain constant region (Ig C $\lambda$ ), and Ig $\kappa$ variable region $(\mathrm{V} \kappa / \mathrm{J} \kappa)$ transcripts correspond to the 340, 231, 316, and the $340 \mathrm{bp} \mathrm{SqRT-PCR} \mathrm{products,} \mathrm{respectively.} \mathrm{HMC,} \mathrm{human} \mathrm{mesangial} \mathrm{cell;} \mathrm{PBS,}$ phosphate-buffered saline; SqRT-PCR, semi-quantitative reverse transcription-polymerase chain reaction; PBMC, peripheral blood mononuclear cell as positive control; negative control: PCR reaction mixture with water; CD19, The B lymphocyte marker.

and less diverse than the transcripts from PBMCs (Table IV).

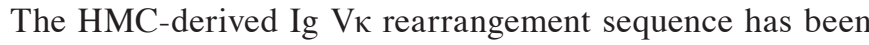
submitted to the GenBank database (GenBank accession no. KX443559).

Dynamic expression of IgA in HMCs during cell cycle and IgA secretion. Double thymidine (TdR) block model was used to achieve HMCs synchronous growth and the cells were harvested every $2 \mathrm{~h}$ to detect the IgA expression at different phases of the cell cycle. The cell cycle phase was determined by flow cytometry and demonstrated that HMCs entered S phase at around $2 \mathrm{~h}, \mathrm{G} 2 / \mathrm{M}$ phase from 4 to $6 \mathrm{~h}$, G0/G1 phase from $8 \mathrm{~h}$ to $10 \mathrm{~h}$, and re-entered into $\mathrm{S}$ phase $12 \mathrm{~h}$ later (Fig. 4A).

Consistent with the cell cycle phases, we detected dynamic expressions of Ig $\alpha 1$ (Fig. 4B and C) and Ig $\alpha 2$ (data not shown). The immunostaining results showed that Ig $\alpha 1$ expression was gradually increased from $\mathrm{S}$ phase $(2 \mathrm{~h})$, then reached highest levels at the G2/M phase (4-6 h), decreased after the G0/G1 phase $(10 \mathrm{~h})$ and increased in $\mathrm{S}$ phase (12 to $24 \mathrm{~h}$ ) again. Different protein expression levels were also detected in the cell lysates by Western blot analysis (Fig. 4D and E). The trend of the Ig $\alpha$ heavy chain expression at 4 and $10 \mathrm{~h}$ by Western blot was similar with that by IF staining. The $\alpha$ chain displayed a differential localization pattern and expression levels during the $24 \mathrm{~h}$ observation period after synchronization. These changes were in accordance with the cell G, S and M phases, indicating that the IgA heavy chain may be associated with cell growth, proliferation and division.

To find out whether HMCs could secrete IgA, we purified Ig $\alpha 1$ from the culture supernatant using jacalin-sepharose which binds to human IgA1 with high specificity. The size of the eluted protein was $65 \mathrm{kDa}$, according to the anti-human Ig $\alpha$ and the Ig $\alpha 1$ antibodies staining, which corresponds to the molecular size for the Ig $\alpha$ heavy chain (Fig. 4F). Mass spectra results showed that there was high homology between the amino acid sequences of the band and those of the Ig $\alpha 1$ and Ig $\alpha 2$ constant regions published in the NCBI database (GenBank, CAC20453.1, AAB30803.1) (Fig. 5).

Up-regulation of IgA in HMCs by AngII. We utilized AngII, endogenous pro-inflammatory factor, to examine the effects 


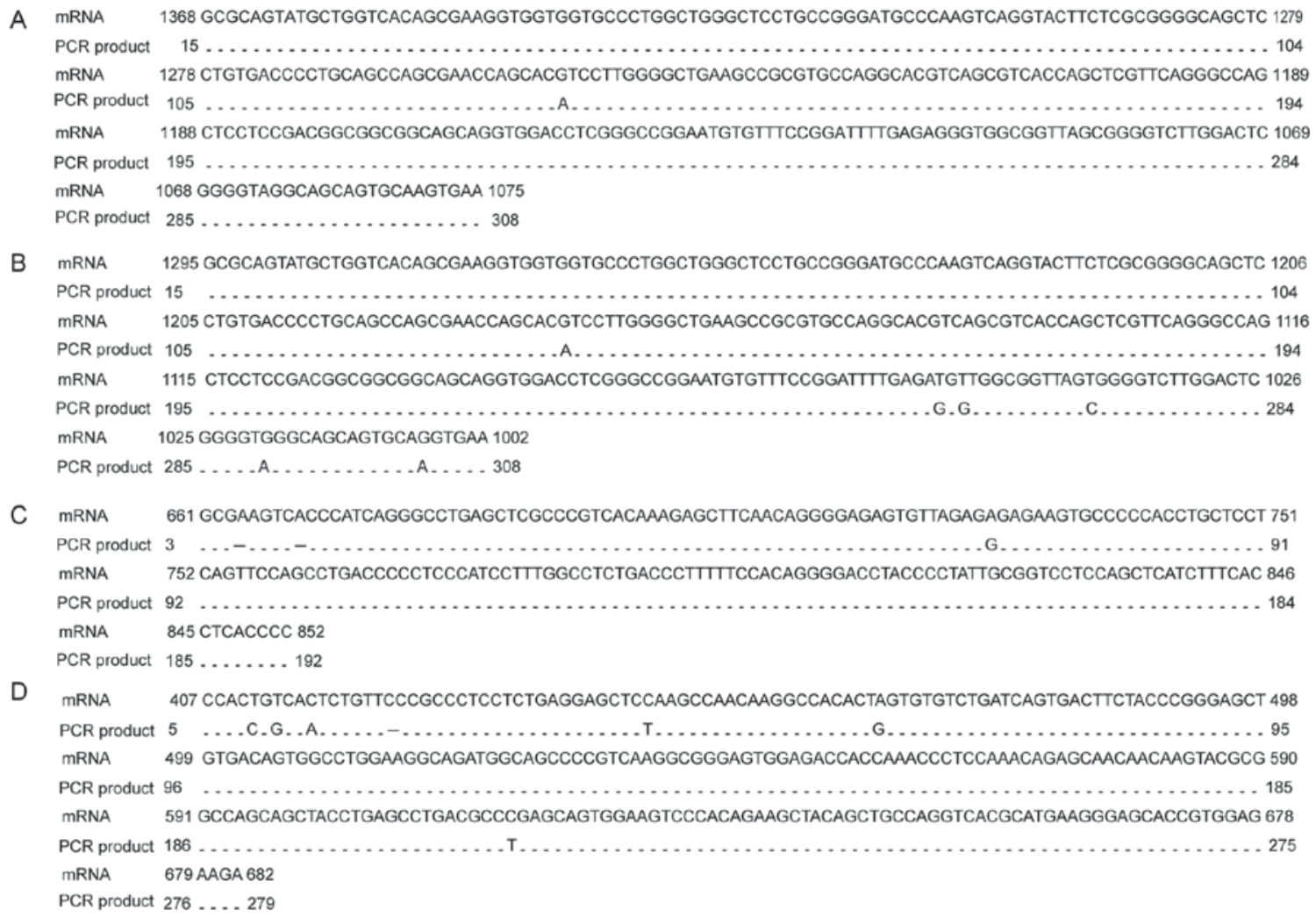

Figure 3. Alignment of the SqRT-PCR products sequences with the mRNA sequences from the NCBI database. (A-D) Alignment of the SqRT-PCR products sequences from HMCs with those of the Ig C $\alpha 1$, Ig C $\alpha 2$, Ig C $\kappa$ and Ig C $\lambda$ mRNA sequences from the NCBI database (Gene Bank, BC016369.1, BC073765.1, Y14736.1, X57823.1). SqRT-PCR, semi-quantitative reverse transcription-polymerase chain reaction; NCBI, National Center for Biotechnology Information; HMC, human mesangial cell.

of pro-inflammatory factors on the IgA expression in HMCs. $24 \mathrm{~h}$ after AngII stimulation, the immunofluorescence staining was stronger for Ig $\alpha, \operatorname{Ig} \kappa, \operatorname{Ig} \lambda$ in the cytoplasm (Fig. 6A). Ig $\alpha$ and $\operatorname{Ig} \lambda$ were more abundant on the fibrous structures in the cytoplasm and a granular accumulation was observed on the cell membranes. Similar to the WB results immunostaining revealed that Ig $\kappa$ was expressed weakly in HMCs and its accumulation on the membranes was not obvious.

The association of IgA with cell apoptosis and cell adhesion. To investigate the possible effects of HMC-produced IgA on cell functions, we used the siRNA transfection method to down regulate the expression of Ig $\alpha 1$ in HMCs. After transfection with siRNAs for $48 \mathrm{~h}$, the cells were collected to detect the Ig $\alpha 1$ expression in HMCs. The relative expression of the $53 \mathrm{kDa}$ form of the Ig $\alpha 1$ was significantly downregulated in the siRNA-1 and the siRNA-3 treated groups compared to the negative control (NC) group $(0.32 \pm 0.01$ vs. $0.73 \pm 0.05, \mathrm{P}<0.05$; $0.36 \pm 0.01$ vs. $0.73 \pm 0.05, P<0.05$, respectively) and this was also similar with the expression of the $38 \mathrm{kDa}$ form $(0.34 \pm 0.01 \mathrm{vs}$. $0.58 \pm 0.03, \mathrm{P}<0.05 ; 0.26 \pm 0.02$ vs. $0.58 \pm 0.03, \mathrm{P}<0.05$ ) (Fig. $6 \mathrm{~B}$ and $\mathrm{C}$ ). These results indicated that siRNA-1 and siRNA-3 transfection could effectively down-regulate IgA in HMCs.

Annexin $\mathrm{V}$ assay combined with flow cytometry was performed to evaluate the apoptosis rates. After siRNA transfection for $48 \mathrm{~h}$, early apoptosis in HMCs was detected. Apoptosis in the HMCs siRNA-1 and the siRNA-3 groups showed an early increase compared with that in the NC group $(20.45 \pm 5.34$ vs. $10.27 \pm 5.31 \%, \mathrm{P}<0.05 ; 27.25 \pm 9.81$ vs.
10.27 $\pm 5.31 \%, \mathrm{P}<0.05, \mathrm{n}=4$ ) (Fig. $6 \mathrm{D}$ and $\mathrm{E}$ ), indicating that IgA expression in HMCs might play an important role in cell growth and apoptosis. Cell adhesion ability is important for HMCs to execute functions such as structural support of the capillary tuft, modulation of glomerular hemodynamics and phagocytic removal of macromolecules and immune complexes. After siRNA transfection for $48 \mathrm{~h}$, cell adhesion rates of HMCs in both the siRNA-1 and the siRNA-3 groups were significantly decreased compared to the NC group $(34.99 \pm 2.56$ vs. $46.88 \pm 6.70 \%, \mathrm{P}<0.05 ; 27.16 \pm 4.67$ vs. $46.88 \pm 6.70 \%, \mathrm{P}<0.05$ ) (Fig. $6 \mathrm{~F}$ ). The significant decrease of cell adhesion rates indicated that the knockdown of IgA in HMCs might inhibit cell adhesion. These changes in the rate of early apoptosis and the ability to adhere indicated that $\operatorname{Ig} \mathrm{A}$ expression is associated with mesangial cell functions.

\section{Discussion}

Definitive diagnosis of IgAN requires a kidney biopsy and IgAN is identified immunohistologically by the presence of dominant or co-dominant glomerular deposits of IgA (39), which had been generally considered to be B cell derived. The deposits consist predominantly of polymeric IgA structures of the IgA1 subclass (40). The pathogenic IgA deposition in the glomerular mesangium can activate mesangial cells and induce mesangial hyper-cellularity, apoptosis, oxidative stress, activation of complement, scarring in the glomerular and interstitial compartments, and secretion of pro-inflammatory factors, causing symptoms such as proteinuria, hematuria, and 

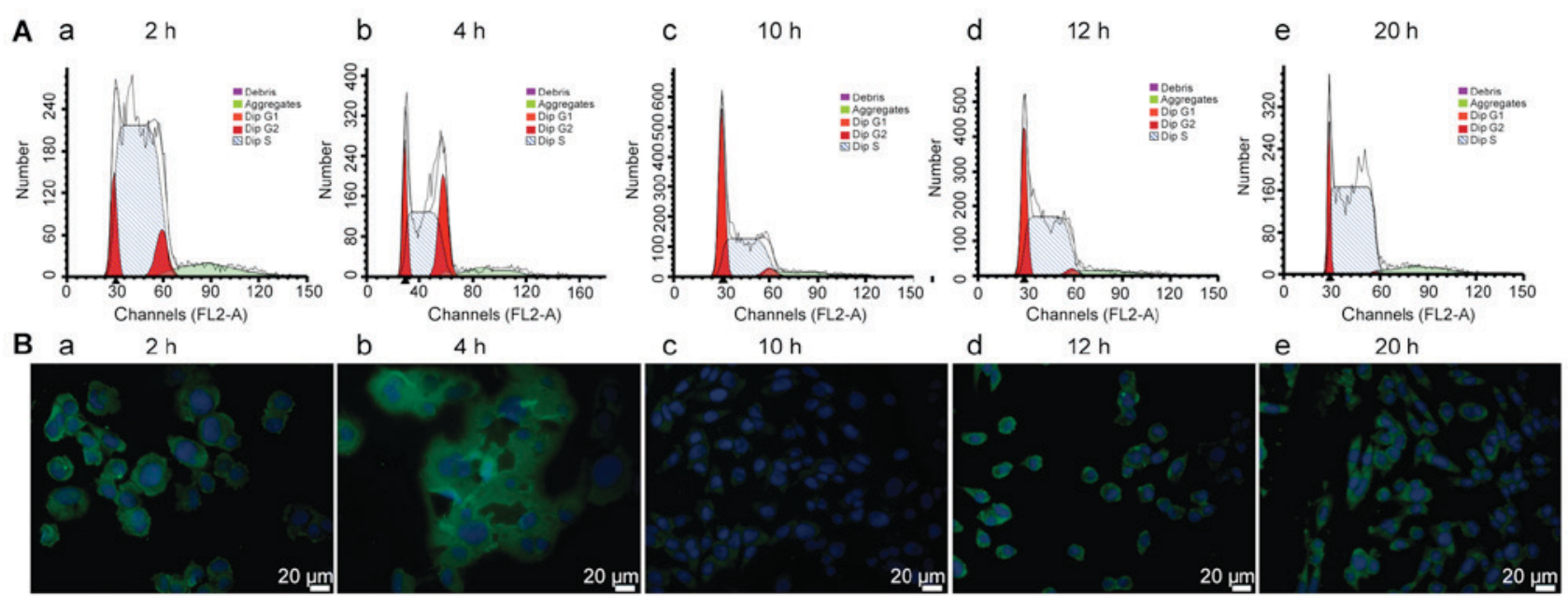

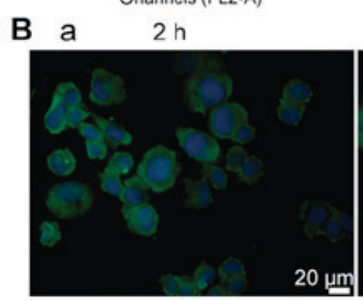

C

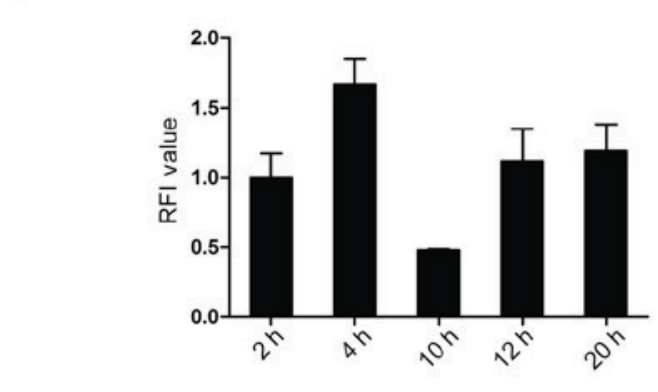

D

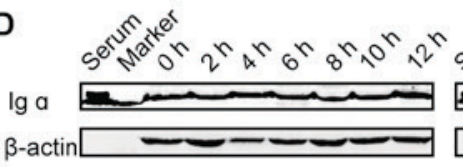

$\beta$-actin

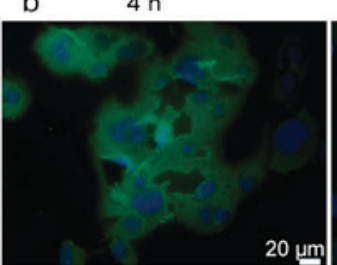

西
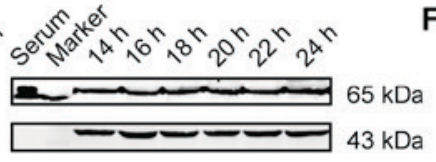

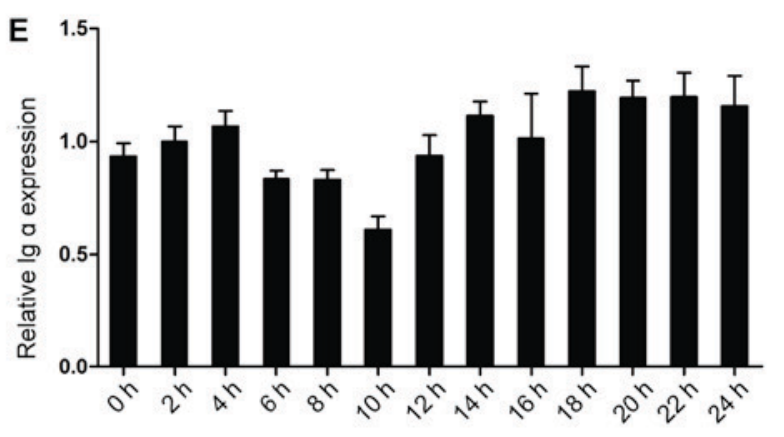

$\mathbf{F}$

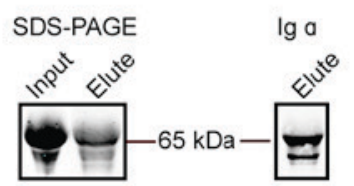

Figure 4. Dynamic detection of Ig $\alpha$ expression in HMCs and secretion. (A) The cell cycle analysis by flow cytometry from 2 to $24 \mathrm{~h}$ (a-e). (B and C) Ig $\alpha 1$ expression was measured as the RFI at different time points from 2 to $24 \mathrm{~h}$ by immunofluorescence staining. Green, antibody staining; blue, nuclear staining with DAPI; scale bar, $20 \mu \mathrm{m}$. (D and E) Expression of Ig $\alpha$ in the cell lysates at different time points after synchronization of HMCs. The data were standardized to the levels of $\beta$-actin. (F) The $65 \mathrm{kDa}$ protein band of Ig $\alpha$ collected from the culture supernatant and purified by affinity chromatography with jacalin-sepharose; the band was further analyzed by mass spectrometry. HMC, human mesangial cell; RFI, relative fluorescence intensity; SDS-PAGE, sodium dodecylsulfate-polyacrylamide gel electrophoresis.

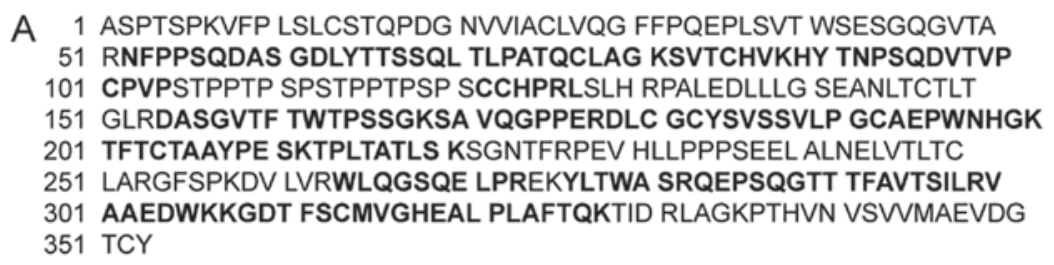
B 1 ASPTSPKVFP LSLDSTPQDG NVVACLVQG FFPQEPLSVT WSESGQNVTA 51 RNFPPSQDAS GDLYTTSSQL TLPATQCPDG KSVTCHVKHY TNPSQDVTVP 101 CPVPPPPPCC HPRLSLHRPA LEDLLLGSEA NLTCTLTGLR DASGATFTWT 151 PSSGKSAVQG PPERDLCGCY SVSSVLPGCA QPWNHGETFT CTAAHPELKT 201 PLTANITKSG NTFRPEVHLL PPPSEELALN ELVTLTCLAR GFSPKDVLVR 251 WLQGSQELPR EKYLTWASRQ EPSQGTTTFA VTSILRVAAE DWKKGDTFSC 301 MVGHEALPLA FTQKTIDRMA GKPTHVNVSV VMAEVDGTCY

Figure 5. Mass spectrometry results of the affinity purified $65 \mathrm{kDa}$ protein band detected in the culture supernatant of the HMCs by immunostaining. Alignment of the amino acid sequence of the protein band from HMCs and those of Ig $\alpha 1$ (A) and Ig $\alpha 2$ (B) constant region sequences from the NCBI database. The black bolded letters indicated the matching amino acids from mass spectrometry results and NCBI database in the alignment. HMC, human mesangial cell; NCBI, National Center for Biotechnology Information.

leading to $\operatorname{Ig} \mathrm{AN}$ (41-43). Igs expression in non-B cells has been reported in recent years by several studies, which provided clues for IgA expression in mesangial cells (11,14,37). Our study demonstrated, for the first time, that mesangial cells 
A
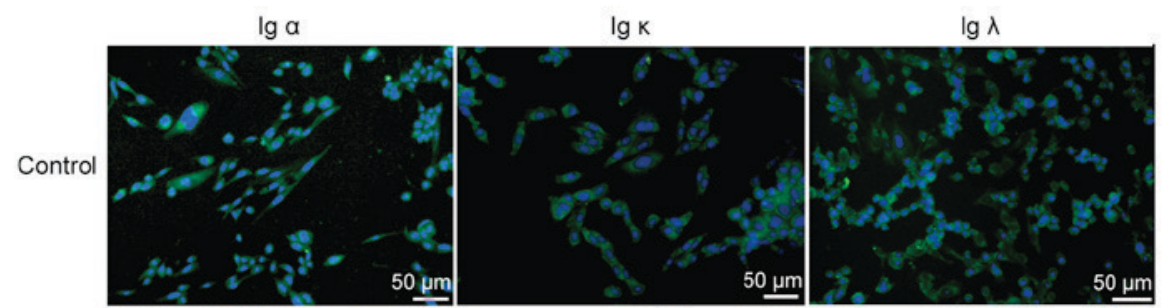

Angll
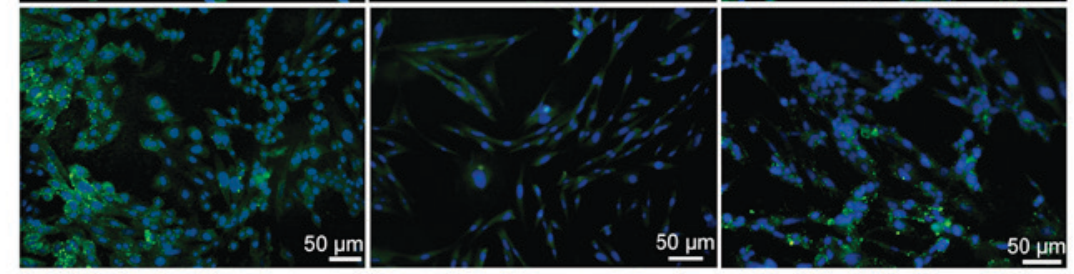

B

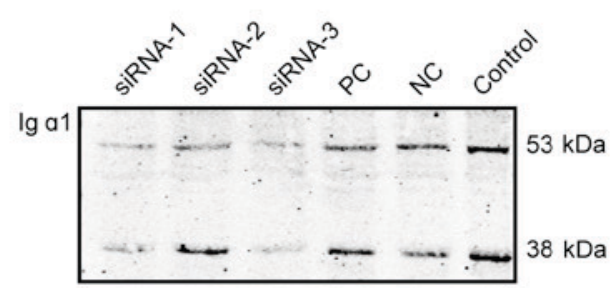

C
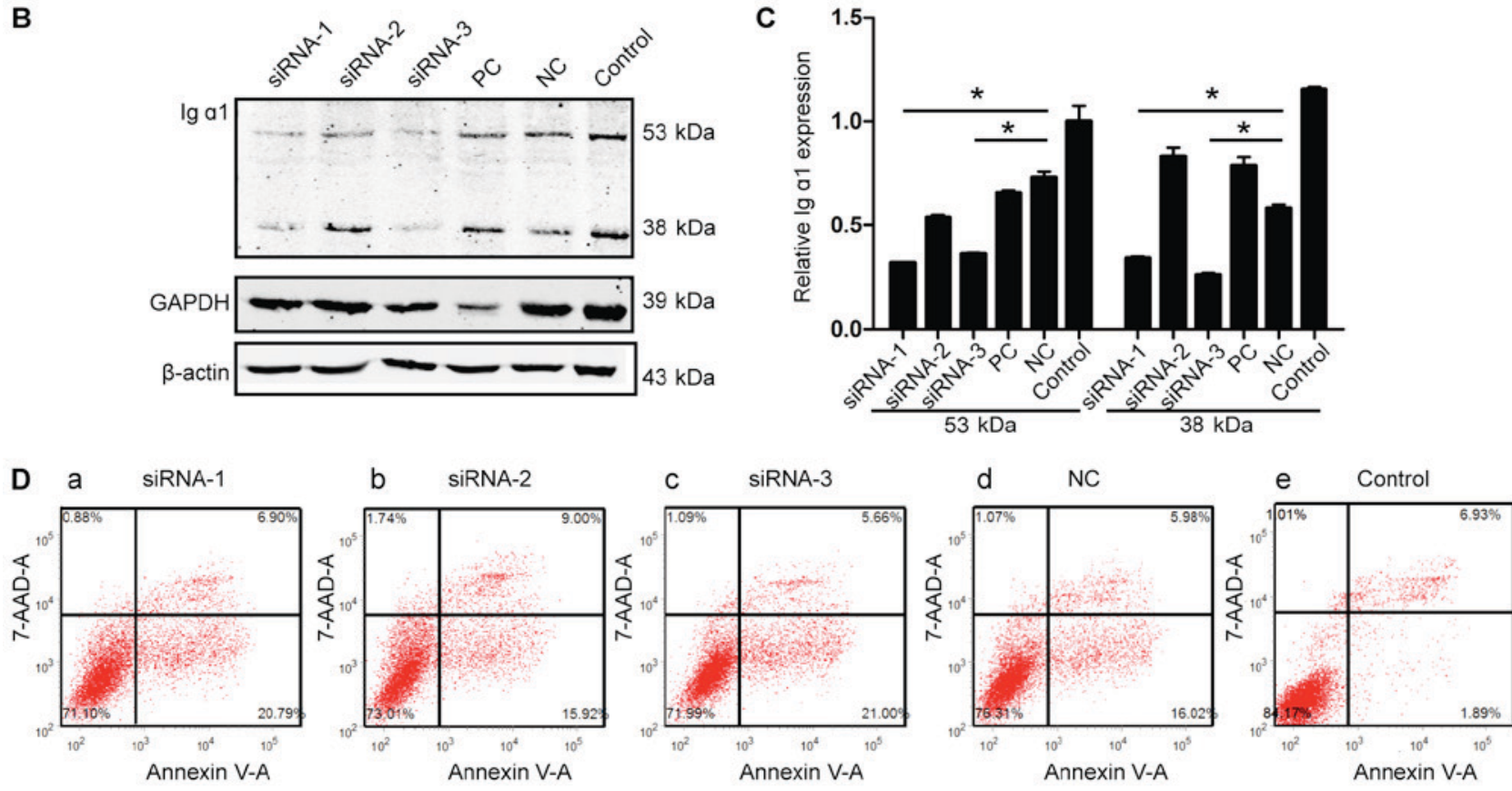

E
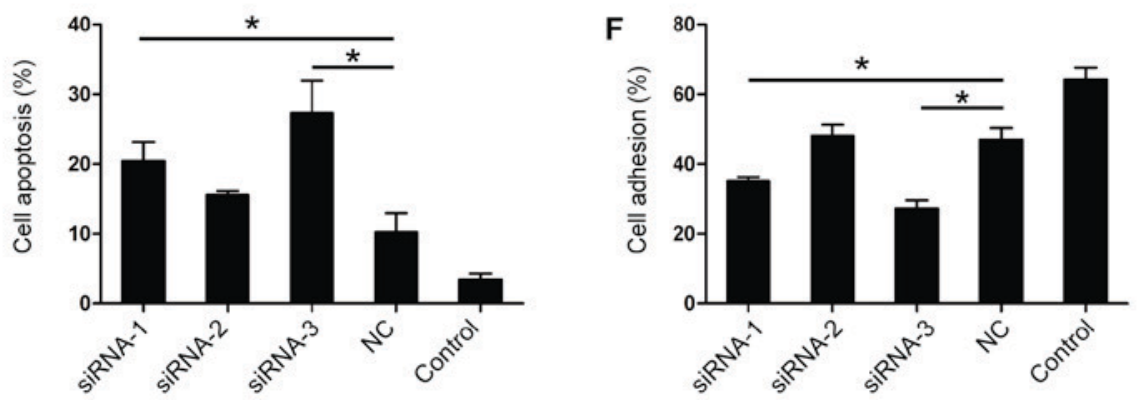

Figure 6. IgA expression after AngII stimulation and its effects on cell apoptosis and adhesion. (A) The positive expression of the Ig $\alpha$, Ig $\kappa$ and Ig $\lambda$ proteins in HMCs, and after stimulation with AngII for $24 \mathrm{~h}$, detected by immunofluorescence staining; scale bar, $50 \mu \mathrm{m}$; (B) Representative western blot images of Ig $\alpha 1$ knockdown in HMCs. (C) The expression rate of the 53 and the $38 \mathrm{kDa}$ band of Ig $\alpha 1$ proteins; after Ig $\alpha 1$ siRNA-1 and siRNA- 3 transfection for $48 \mathrm{~h}$; transfection with siRNA-1 and siRNA-3 was repeated three times. The data were standardized to the levels of $\beta$-actin. (D and E) The rate of cell apoptosis after Ig $\alpha 1$ siRNA transfection for $48 \mathrm{~h} ; \mathrm{n}=4$. (F) Cell adhesion of HMCs after siRNA transfection for $48 \mathrm{~h} ; \mathrm{n}=3$. "P<0.05 vs. NC. siRNA-1, siRNA-2, siRNA-3: siRNA constructs targeting different regions of the Ig $\alpha 1$ heavy chain constant region; PC, positive control: siRNA targeted GAPDH; NC, negative control: Nonspecific, scrambled siRNA. HMC, human mesangial cell; siRNA, small interfering RNA.

may produce and secret $\operatorname{Ig} \mathrm{A}$, and that the deposited $\operatorname{Ig} \mathrm{A}$ in the mesangium of patients with IgAN may be, at least partially, originated from mesangial cells.

In addition, in this study, we have demonstrated that the $\operatorname{Ig} \alpha$, Ig $\kappa$ and $\operatorname{Ig} \lambda$ proteins are present in HRMCs and HMCs, and that their presence was not due to artificial contamination by B lymphocytes or by the FBS buffer in the culture media. These results confirm that the IgA, especially IgA1, is expressed in the mesangial cells. The different molecular weights of the Ig $\alpha$ heavy chain suggested that Ig synthesis and assembly occur at different stages or that it existed in different truncated or aggregated forms, as it has been previously reported by $\mathrm{Hu}$ et al (44). Furthermore, our study has shown that the IgA heavy and light chain constant and 
variable region gene transcripts and proteins were present in the HRMCs and HMCs and that their high homology with those mRNA sequences in the NCBI database strongly supports IgA expression in mesangial cells,. The unique or dominant $\mathrm{Ig} \mathrm{V} \kappa_{\kappa}$ sequences in non-B cells are consistent with other reports $(26,37)$.

Increase of early apoptosis and decrease of cell adhesion ability in HMCs after IgA downregulation were observed in our study, which indicated that expression of $\operatorname{Ig} \alpha 1$ might be associated with mesangial cell functions such as apoptosis, proliferation, and adhesion. IgA mediated cell proliferation and apotosis has been reported in human epithelial cancer cells, but the mechanism was not investigated (45). Previous studies have shown that the pathogenesis of a variety of renal diseases is highly correlated with cell apoptosis and changes of apoptotic genes, in which the Bcl-2 family is one of the most implicated gene families $(46,47)$. Besides, active effector caspases could proteolytically degrade a range of intracellular proteins during the apoptosis process $(48,49)$. IgA expression may participate in the transcriptional and/or post-translational regulation of apoptosis related genes or proteins, such as caspases, to inhibit mesangial cell apoptosis. The specific molecules contributing to cell adhesion between the mesangial cell and the glomerular basement membrane are not clear. However, the protein called Epithelial Protein Lost In Neoplasm (EPLIN) was reported to strongly express in glomerular mesangial cells (50). EPLIN is implicated in the organization of the actin cytoskeleton, during the cell-cell or cell-matrix interactions (51). The above evidence provide us with clues to explore the underlying mechanism(s) regulating IgA expression in mesangial cells and mediating apoptosis and adhesion.

The results of our study have potential application and significance in clinical practice. First, the facts that IgA could be expressed in mesangial cell and secreted out of cell can illustrate that the $\operatorname{IgA}$ deposited in the mesangium in patients with IgAN may be, at least partially, originated from mesangial cells and may induce mesangial cells proliferation and secretion of extracellular matrixes. Second, our results have shown that mesangial cell-derived $\operatorname{IgA}$ is required for physiological cell functions, so exploring the factors which could lead to $\operatorname{Ig}$ A deposition in the mesangium would be of great clinical significance. Third, the upregulation of $\operatorname{Ig} \alpha, \operatorname{Ig} \kappa, \operatorname{Ig} \lambda$ expression by AngII in the cytoplasm of HMCs indicates that an interaction exists between angiotensin and $\operatorname{IgA}$. This interaction can be potentially targeted for the clinical treatment of IgAN by exploiting angiotensin converting enzyme inhibitors or AngII receptor blockers.

Several points in the study need to be further clarified. First, IF staining demonstrated the presence of the $\kappa$ chain in the cytoplasm and RT-PCR identified the transcript of the $k$ chain in the HMCs, but WB was not able to detect the Ig $\kappa$ band. Generally speaking, antibodies used in IF recognize the three-dimensional structure while those in WB bind to the short line chain of the proteins, therefore the IF staining results are more convincing. The negative result in the WB might be attributed to the insufficient recognition by the antibodies. Secondly, a $65 \mathrm{kDa}$ band after jacalin affinity chromatography was positively detected with antibodies against $\operatorname{Ig} \alpha$ and $\operatorname{Ig} \alpha 1$ but not Ig $\alpha 2$, however both $\alpha 1$ and $\alpha 2$ heavy chains were detected in the band by mass spectrometry. IF demonstrated the staining of both $\alpha 1$ and $\alpha 2$ in the cytoplasm and RT-PCR showed that the transcripts of both $\alpha 1$ and $\alpha 2$ were expressed in HMCs. The dominant expression of $\operatorname{Ig} \alpha 1$, as we found by IF and by WB, may compete with the binding of the antibody to the $\operatorname{Ig} \alpha 2$. It was not easy to explain the affinity of jacalin to Ig $\alpha 2$, which was considered not to have any glycosylation sites at the hinge area, and it was unclear if the glycosylation at the hinge area of $\operatorname{Ig} \alpha 1$ and $\operatorname{Ig} \alpha 2$ in the mesangial cells was different from those in the plasm cell.

In conclusion, this study demonstrates that mesangial cells can express and secret IgA and that this expression may be associated with cell functions. Our findings provide clues for the implication of the HMC-produced $\operatorname{IgA}$ in the excessive deposition of $\operatorname{Ig} \mathrm{A}$ in the pathogenesis of IgAN.

\section{Acknowledgements}

We thank Professor Youfei Guan (Department of Physiology and Pathophysiology, Peking University Health Science Center, Peking, China) for supplying the C2M12 cell line, and the Department of Immunology, Peking University, for supporting our work. This study was supported by the National Natural Science Foundation of China (nos. 91229102 and 81272237).

\section{References}

1. Zhou X, Workeneh B, Hu Z and Li R: Effect of immunosuppression on the human mesangial cell cycle. Mol Med Rep 11: 910-916, 2015.

2. Tomana M, Matousovic K, Julian BA, Radl J, Konecny K and Mestecky J: Galactose-deficient IgA1 in sera of IgA nephropathy patients is present in complexes with IgG. Kidney Int 52: 509-516, 1997.

3. Tomana M, Novak J, Julian BA, Matousovic K, Konecny K and Mestecky J: Circulating immune complexes in IgA nephropathy consist of IgA1 with galactose-deficient hinge region and antiglycan antibodies. J Clin Invest 104: 73-81, 1999.

4. Conley ME, Cooper MD and Michael AF: Selective deposition of immunoglobulin A1 in immunoglobulin A nephropathy, anaphylactoid purpura nephritis, and systemic lupus erythematosus. J Clin Invest 66: 1432-1436, 1980.

5. Novak J, Moldoveanu Z, Renfrow MB, Yanagihara T, Suzuki H, Raska M, Hall S, Brown R, Huang WQ, Goepfert A, et al: IgA nephropathy and Henoch-Schoenlein purpura nephritis: Aberrant glycosylation of IgA1, formation of IgA1-containing immune complexes, and activation of mesangial cells. Contrib Nephrol 157: 134-138, 2007.

6. Reily C, Ueda H, Huang ZQ, Mestecky J, Julian BA, Willey CD and Novak J: Cellular signaling and production of galactosedeficient IgA1 in IgA nephropathy, an autoimmune disease. J Immunol Res 2014: 197548, 2014.

7. Qiu X and Yang G: Existance of Ig-like protein in malignant tumor cells. J Norman Bethune Univ Med Sci 22: 572,574,575, 1996.

8. Qiu X and Yang G: The characteristic and gene structure of Ig-like protein in maligant tumor. Chin J Immun 295, 1996 (In Chinese).

9. Kimoto Y: Expression of heavy-chain constant region of immunoglobulin and T-cell receptor gene transcripts in human non-hematopoietic tumor cell lines. Genes Chromosomes Cancer 22: 83-86, 1998

10. Zheng H, Li M, Ren W, et al: Expression and secretion of immunoglobulin alpha heavy chain with diverse VDJ recombinations by human epithelial cancer cells. Mol Immunol 44: 2221-2227, 2007.

11. Qiu X, Zhu X, Zhang L, Mao Y, Zhang J, Hao P, Li G, Lv P, Li Z, Sun X, et al: Human epithelial cancers secrete immunoglobulin $\mathrm{g}$ with unidentified specificity to promote growth and survival of tumor cells. Cancer Res 63: 6488-6495, 2003. 
12. Zhu X, Li C, Sun X, Mao Y, Li G, Liu X, Zhang Y and Qiu X Immunoglobulin mRNA and protein expression in human oral epithelial tumor cells. Appl Immunohistochem Mol Morphol 16: 232-238, 2008

13. Babbage G, Ottensmeier CH, Blaydes J, Stevenson FK and Sahota SS: Immunoglobulin heavy chain locus events and expression of activation-induced cytidine deaminase in epithelial breast cancer cell lines. Cancer Res 66: 3996-4000, 2006.

14. Zheng H, Li M, Ren W, Zeng L, Liu HD, Hu D, Deng X, Tang M, Shi Y, Gong J and Cao Y: Expression and secretion of immunoglobulin alpha heavy chain with diverse VDJ recombinations by human epithelial cancer cells. Mol Immunol 44: 2221-2227, 2007.

15. Chen $\mathrm{Z}$ and $\mathrm{Gu} \mathrm{J}$ : Immunoglobulin $\mathrm{G}$ expression in carcinomas and cancer cell lines. FASEB J 21: 2931-2938, 2007.

16. Li M, Feng DY, Ren W, Zheng L, Zheng H, Tang M and Cao Y: Expression of immunoglobulin kappa light chain constant region in abnormal human cervical epithelial cells. Int J Biochem Cel Biol 36: 2250-2257, 2004

17. Wang C, Xia M, Sun X, He Z, Hu F, Chen L, Bueso-Ramos CE, Qiu X and Yin CC: IGK with conserved IGKV/IGKJ repertoire is expressed in acute myeloid leukemia and promotes leukemic cell migration. Oncotarget 6: 39062-39072, 2015.

18. Jiang C, Huang T, Wang Y, Huang G, Wan $\mathrm{X}$ and $\mathrm{Gu} \mathrm{J}$ : Immunoglobulin $\mathrm{G}$ expression in lung cancer and its effects on metastasis. PLoS One 9: e97359, 2014.

19. Wang J, Lin D, Peng H, Huang Y, Huang J and Gu J: Cancerderived immunoglobulin $G$ promotes tumor cell growth and proliferation through inducing production of reactive oxygen species. Cell Death Dis 4: e945, 2013.

20. Wen YJ, Mancino A, Pashov A, Whitehead T, Stanley J and Kieber-Emmons T: Antigen binding of human IgG Fabs mediate ERK-associated proliferation of human breast cancer cells. DNA Cell Biol 24: 73-84, 2005.

21. Liang PY, Li HY, Zhou ZY, Jin YX, Wang SX, Peng XH and Ou SJ: Overexpression of immunoglobulin G prompts cell proliferation and inhibits cell apoptosis in human urothelial carcinoma. Tumour Biol 34: 1783-1791, 2013.

22. Pan B, Zheng S, Liu C and Xu Y: Suppression of IGHG1 gene expression by siRNA leads to growth inhibition and apoptosis induction in human prostate cancer cell. Mol Biol Rep 40: 27-33, 2013.

23. Huang J, Sun X, Mao Y, Zhu X, Zhang P, Zhang L, Du J and Qiu X: Expression of immunoglobulin gene with classical $\mathrm{V}$-(D)-J rearrangement in mouse brain neurons. Int J Biochem Cell Biol 40: 1604-1615, 2008.

24. Huang J, Sun X, Gong X, He Z, Chen L, Qiu X and Yin CC: Rearrangement and expression of the immunoglobulin $\mu$-chain gene in human myeloid cells. Cell Mol Immunol 11: 94-104, 2014.

25. Huang J, Zhang L, Ma T, Zhang P and Qiu X: Expression of immunoglobulin gene with classical V-(D)-J rearrangement in mouse testis and epididymis. J Histochem Cytochem 57: 339-349, 2009.

26. Zhang S, Mao Y, Huang J, Ma T, Zhang L, Zhu X, Zheng J, Wu L, Yin CC and Qiu X: Immunoglobulin gene locus events in epithelial cells of lactating mouse mammary glands. Cell Mol Life Sci 67: 985-994, 2010.

27. Liu J, Xia M, Wang P, Wang C, Geng Z, Cameron Yin C, Zhang C and Qiu X: Immunoglobulin gene expression in umbilical cord blood-derived $\mathrm{CD} 34^{+}$hematopoietic stem/progenitor cells. Gene 575: 108-117, 2016.

28. Kang BY, Hu C, Prayaga S, Khaidakov M, Sawamura T, Seung KB and Mehta JL: LOX-1 dependent overexpression of immunoglobulins in cardiomyocytes in response to angiotensin II. Biochem Biophys Res Commun 379: 395-399, 2009.

29. Niu N, Zhang J, Sun Y, Wang S, Sun Y, Korteweg C, Gao W and $\mathrm{Gu} \mathrm{J}$ : Expression and distribution of immunoglobulin $\mathrm{G}$ and its receptors in an immune privileged site: The eye. Cell Mol Life Sci 68: 2481-2492, 2011.

30. Lei Y, Huang T, Su M, Luo J, Korteweg C, Li J, Chen Z, Qiu Y, Liu X, Yan M, et al: Expression and distribution of immunoglobulin $\mathrm{G}$ in the normal liver, hepatocarcinoma and postpartial hepatectomy liver. Lab Invest 94: 1283-1295, 2014.

31. Wang S, Huang G, Wang Y, Huang T, Lin S and Gu J: Up-regulation of immunoglobulin $\mathrm{G}$ gene expression in the hippocampus of rats subjected to acute immobilization stress. J Neuroimmunol 258: 1-9, 2013.

32. Ruan XZ, Varghese Z, Fernando R and Moorhead JF: Cytokine regulation of low-density lipoprotein receptor gene transcription in human mesangial cells. Nephrol Dial Transplant 13: 1391-1397, 1998.
33. Sraer JD, Delarue F, Hagege J, Feunteun J, Pinet F, Nguyen G and Rondeau E: Stable cell lines of T-SV40 immortalized human glomerular mesangial cells. Kidney Int 49: 267-270, 1996.

34. Prendergast L, van Vuuren C, Kaczmarczyk A, Doering V, Hellwig D, Quinn N, Hoischen C, Diekmann S and Sullivan KF: Premitotic assembly of human CENPs-T and -W switches centromeric chromatin to a mitotic state. PLoS Biol 9: e1001082, 2011

35. Coldwell MJ, Cowan JL, Vlasak M, Mead A, Willett M, Perry LS and Morley SJ: Phosphorylation of eIF4GII and 4E-BP1 in response to nocodazole treatment: A reappraisal of translation initiation during mitosis. Cell Cycle 12: 3615-3628, 2013.

36. Jose S, Tan SW, Ooi YY, Ramasamy R and Vidyadaran S: Mesenchymal stem cells exert anti-proliferative effect on lipopolysaccharide-stimulated BV2 microglia by reducing tumour necrosis factor- $\alpha$ levels. J Neuroinflammation 11: 149 , 2014.

37. Zheng J,Huang J, Mao Y,Liu S, Sun X,Zhu X, Ma T,Zhang L, Ji J, Zhang Y, et al: Immunoglobulin gene transcripts have distinct VHDJH recombination characteristics in human epithelial cancer cells. J Biol Chem 284: 13610-13619, 2009.

38. Brown TT, Jr., Schultz RD, Duncan JR and Bistner SI: Serological response of the bovine fetus to bovine viral diarrhea virus. Infect Immun 25: 93-97, 197.

39. Roberts IS: Pathology of IgA nephropathy. Nat Rev Nephrol 10: 445-454, 2014

40. Valentijn RM, Radl J, Haaijman JJ, Vermeer BJ, Weening JJ, Kauffmann RH, Daha MR and van Es LA: Circulating and mesangial secretory component-binding IgA-1 in primary IgA nephropathy. Kidney Int 26: 760-766, 1984.

41. Novak J, Julian BA, Mestecky J and Renfrow MB Glycosylation of $\operatorname{IgA} 1$ and pathogenesis of $\operatorname{Ig}$ A nephropathy. Semin Immunopathol 34: 365-382, 2012.

42. Lai KN, Leung JC, Chan LY, Saleem MA, Mathieson PW, Lai FM and Tang SC: Activation of podocytes by mesangial-derived TNF-alpha: Glomerulo-podocytic communication in Ig A nephropathy. Am J Physiol Renal Physiol 294: F945-F955, 2008.

43. Lai KN: Pathogenesis of IgA nephropathy. Nat Rev Nephrol 8: 275-283, 2012.

44. Hu D, Duan Z, Li M, Jiang Y, Liu H, Zheng H, Li L, Bode AM, Dong $\mathrm{Z}$ and Cao Y: Heterogeneity of aberrant immunoglobulin expression in cancer cells. Cell Mol Immunol 8: 479-485, 2011.

45. Zheng H, Li M, Liu H, Ren W, Hu DS, Shi Y, Tang M and Cao Y: Immunoglobulin alpha heavy chain derived from human epithelial cancer cells promotes the access of $\mathrm{S}$ phase and growth of cancer cells. Cell Biol Int 31: 82-87, 2007.

46. Kang BP, Urbonas A, Baddoo A, Baskin S, Malhotra A and Meggs LG: IGF-1 inhibits the mitochondrial apoptosis program in mesangial cells exposed to high glucose. Am J Physiol Renal Physiol 285: F1013-F1024, 2003.

47. Qiu LQ, Sinniah R and I-Hong Hsu S: Downregulation of Bcl-2 by podocytes is associated with progressive glomerular injury and clinical indices of poor renal prognosis in human $\operatorname{IgA}$ nephropathy. J Am Soc Nephrol 15: 79-90, 2004.

48. Denault JB and Salvesen GS: Caspases: Keys in the ignition of cell death. Chem Rev 102: 4489-4500, 2002.

49. Philchenkov AA: Caspases as regulators of apoptosis and other cell functions. Biochemistry (Mosc) 68: 365-376, 2003.

50. Tsurumi H, Harita Y, Kurihara H, Kosako H, Hayashi K, Matsunaga A, Kajiho Y, Kanda S, Miura K, Sekine T, et al: Epithelial protein lost in neoplasm modulates platelet-derived growth factor-mediated adhesion and motility of mesangial cells. Kidney Int 86: 548-557, 2014.

51. Karaköse E, Geiger T, Flynn K, Lorenz-Baath K, Zent R, Mann M and Fässler R: The focal adhesion protein PINCH-1 associates with EPLIN at integrin adhesion sites. J Cell Sci 128: 1023-1033, 2015.

This work is licensed under a Creative Commons Attribution-NonCommercial-NoDerivatives 4.0 International (CC BY-NC-ND 4.0) License. 